\title{
Methylation profiles of thirty four promoter-CpG islands and concordant methylation behaviours of sixteen genes that may contribute to carcinogenesis of astrocytoma
}

\author{
Jian $\mathrm{Yu}^{\dagger 1}$, Hongyu Zhang ${ }^{\dagger 1}$, Jun $\mathrm{Gu}^{1}$, Song $\mathrm{Lin}^{2}$, Junhua $\mathrm{Li}^{2}$, Wei $\mathrm{Lu}^{3}$, \\ Yifei Wang ${ }^{3}$ and Jingde Zhu*1
}

\begin{abstract}
Address: ${ }^{1}$ Cancer Epigenetics and Gene Therapy, State-Key Laboratory for Oncogenes and Related Genes, Shanghai Cancer Institute, Shanghai Jiao Tong University, LN 2200/25, Xie-Tu Road, Shanghai 200032, China, ${ }^{2}$ Department of Neurosurgery, Tiantan Hospital of Capital University of Medical Sciences, Beijing Neurosurgical Institute, Beijing 100050, China and ${ }^{3}$ Department of Mathematics, Shanghai University, No. 99, Shangda Road, Shanghai 200436, P. R. China

Email: Jian Yu - gyujian@hotmail.com; Hongyu Zhang - posset@sina.com.cn; Jun Gu - GuJune@yahoo.com;

Song Lin - linsong@public.fhnet.cn.net; Junhua Li - linsong@public.fhnet.cn.net; Wei Lu - luwei_thomas@163.com; Yifei Wang - yfwang@mail.shu.edu.cn; Jingde Zhu* - zhujingde@yahoo.com

* Corresponding author †Equal contributors
\end{abstract}

Published: 14 September 2004

BMC Cancer 2004, 4:65 doi:10.1 186/147|-2407-4-65
Received: 04 February 2004

Accepted: 14 September 2004

This article is available from: http://www.biomedcentral.com/I47/-2407/4/65

(c) 2004 Yu et al; licensee BioMed Central Ltd.

This is an open-access article distributed under the terms of the Creative Commons Attribution License (http://creativecommons.org/licenses/by/2.0), which permits unrestricted use, distribution, and reproduction in any medium, provided the original work is properly cited.

\begin{abstract}
Background: Astrocytoma is a common aggressive intracranial tumor and presents a formidable challenge in clinic. Association of the altered DNA methylation pattern of the promoter CpG islands with the expression profile of the cancer related genes has been found in many human tumors. Therefore, DNA methylation status as such may serve as the epigenetic biomarker for both diagnosis and prognosis of human tumors including astrocytoma.
\end{abstract}

Methods: We used the methylation specific PCR in conjunction with sequencing verification to establish the methylation profile of the promoter $C_{p G}$ island of thirty four genes in astrocytoma tissues from fifty three patients (The WHO grading:. I: 14, II: 15, III: 12 and IV: 12 cases, respectively). In addition, the compatible tissues (normal tissues distant from lesion) from three non-astrocytoma patients were also included as the control.

Results: Seventeen genes (ABL, APC, APAFI, BRCAI, CSPG2, DAPKI, hMLHI, LKBI, PTEN, pI 4 ARF, pI $5^{I N K 4 b}, p 27^{K I P I}, p 57^{K I P 2}$, RASSFIC, RBI, SURVIVIN, and VHL) displayed a uniformly unmethylated pattern in all the astrocytoma and non-astrocytoma tissues examined. However, the MAGEAI gene that was inactivated and hypermethylated in non-astrocytoma tissues, was partially demethylated in $24.5 \%$ of the astrocytoma tissues (co-existence of the hypermethylated and demethylated alleles). Of the astrocytoma associated hypermethylated genes, the methylation pattern of the CDHI3, cyclin a I, DBCCRI, EPO, MYODI, and pl 6INK4a genes changed in no more than $5.66 \%(3 / 53)$ of astrocytoma tissues compared to non-astrocytoma controls, while the RASSFIA, p73, AR, MGMT, $C D H I, O C T 6, M T I A, W T I$, and IRF7 genes were more frequently hypermethylated in $69.8 \%, 47.2 \%$, $41.5 \%, 35.8 \%, 32 \%, 30.2 \%, 30.2 \%, 30.2 \%$ and $26.4 \%$ of astrocytoma tissues, respectively. Demethylation mediated inducible expression of the CDHI3, MAGEAI, MGMT, p73 and RASSFIA genes was established in an astrocytoma cell line (U25I), demonstrating that expression of these genes is likely regulated by DNA methylation. The AR hypermethylation was found exclusively in female patients $(22 / 27,81 \%, 0 / 26,0 \%, P<0.00 I)$, while the IRF7 hypermethylation preferentially 
occurred in the male counterparts $(1 \mathrm{I} / 26,42.3 \%$ to $3 / 27,1 \mathrm{I} \%, \mathrm{P}<0.05)$. Applying the mathematic method "the Discovery of Association Rules", we have identified the groups consisting of up to three genes that more likely display the altered methylation patterns in concert in astrocytoma.

Conclusions: Of the thirty four genes examined, sixteen genes exhibited astrocytoma associated changes in the methylation profile. In addition to the possible pathological significance, the established concordant methylation profiles of the subsets consisting of two to three target genes may provide useful clues to the development of the useful prognostic as well as diagnostic assays for astrocytoma.

\section{Background}

Diffusely infiltrating astrocytoma is a leading group of the primary central nervous system tumors, accounting for more than $60 \%$ of all primary brain tumors $[1,2]$. It may arise aggressively from the normal astrocytes, or evolve stepwise from the less its benign precursors. Owing to the difficulties with its early diagnosis and surgical removal of all residue diseased tissues, rapid progression, and frequent reoccurrence, the most advanced form of astrocytoma, glioblastoma (WHO grading IV) represents an extremely life-threatening intracranial malignant tumor both inside and outside of China $[1,2]$. Molecular genetic analyses have demonstrated multiple genetic lesions implicating to pathogenesis of astrocytoma, glioblastoma in particular. In addition to the frequent amplification and deletion of the EGF receptor gene (EGFR) [3], the main genetic events affecting the following tumor suppressor genes: the members of the INK4A initiated cellcycle arrest pathway (the p16 $6^{I N K 4 a}$ ) [4], the p14 ${ }^{A R F}$ [5], the $R B 1$ [6] and the $p 53$ [7]), a wide spectrum of the cell surface receptor genes (i.e., CD44, integrin, and receptors for various growth factors), and the PTEN genes [8].

Transcription in eukaryotes is regulated at multiple levels and inversely correlated with the hypermethylated state as well as the chromatin condensation. It has been well established that the methylation status of CpG islands directly affects the DNA-protein interactions by eliminating the otherwise occurring sequence specific binding of the transcription factors whereas inducing the DNA-bindings of members of the methyl-CpG binding protein family (MBD). Histone modifications (deacetylation and methylation) may occur subsequently leading to chromatin condensation and a long-term transcriptional silencing status of the affected DNA segments. Over $40 \%$ of the protein coding genes have at least one $\mathrm{CpG}$ island within or near to their promoter, an strong indication for transcription of which is likely to be under the control of DNA methylation status. Three DNA methyl transferases are involved in the control of the methylation state of the CpGs in genome. DNA methyl transferase I is mainly responsible for the maintenance of the methylation status of the genome after DNA replication, while IIIA and IIIB act principally in the de novo DNA methylation in the early development of high eukaryotes. DNA methylation patterns in somatic cells are established during the early development and contribute to the allele-specific transcription silencing of the imprinted genes, including the silenced alleles in the X-chromosome and other chromosomes. The epigenetic pattern (the DNA methylation profiles of the genome) in high eukaryotes is integral to the normal execution of the biological activities in cells and needs to be actively maintained. In addition to the changes linked to the cell lineage specific pattern of gene expression, both global hypomethylation and local hypermethylation of the CPG islands occur progressively as cell ages.

Aberrant DNA methylation pattern changes gene transcription that has been etiologically linked to cancer formation $[9,10]$. The genome-wide hypomethylation has been believed to activate transcription of the otherwise silenced transposon like repetitive sequences (such as the Alu and LINE repeats in mammals). As a result, the transposition occurs more prevalently so that the genomic instability in cancer cells will be significantly increased [11-13]. The hypermethylated state of the promoter CpG islands has been etiologically associated with transcription inactivation of a number of tumor suppressor genes in tumors, which are hypomethylated and transcribed in their normal counterparts. Therefore, the hypermethylated CpG island(s) of those genes have been regarded as a defect, reminiscent to the loss of heterozygosity or other types of genetic deletion for total inactivation of the tumor suppressor genes in cancer. The most noticeable example is the p16 INK4a gene that has been frequently hypermethylated in almost all types of the tumors examined [14-17] including hepatocellular carcinoma [18]. The loss of the genetic imprinting (changes in DNA methylation status) has been found to reactivate transcription of the otherwise silenced allele of the genes such as the insulin like growth factor 2 gene, which has been well documented in human tumors [19]. On the other hand, the reverse process, i.e., demethylation of the promoter CpG island, has also been found instrumental to the transcription activation of the otherwise inert genes in tumor cells [20]. A prominent example is the gene encoding the melanoma antigen, MAGEA1 that was hypermethylated 
and transcriptionally silenced in the normal liver tissues, and demethylated prevalently in the hepatocellular carcinoma tissues [18], correlating well with the elevated level of its expression in HCC $[21,22]$. The over-expressed gene, SURVIVIN, has also been reported to be demethylated in human ovarian cancer [23]. Despite of the fact that the elevated levels of expression of three DNA methyl transferase genes were detected in virtually all cancers, the profiles of the hypermethylated genes vary with both the types and stages of cancers. Therefore, the undefined defects in the epigenetic homeostasis during carcinogenesis, rather than the aberrant expression of any given DNA methyl transferase, are more likely to account for the cancer type specific pattern of DNA methylation at both global and local levels.

Methylation profiling of the promoter $\mathrm{CpG}$ islands has been an important information gathering process for new insights into our understanding of the role of DNA methylation in both initiation and progression of human carcinogenesis. It would result in development of the DNA methylation based assays for cancer diagnosis as well as identification of the cancer genes suffering from the epigenetic defects http://www.missouri.edu/ hypermet/ list of promoters.htm. However, as the majority of studies had only targeted one or a few genes in rather small patient groups, the concurrent hypermethylation behavior of multiple genes has only been addressed in a limited number of tumor types, such as colorectal cancer. The majority, if not all, of the previous studies on the astrocytoma associated changes in methylation profiles have only examined a small number of genes for methylation status at the promoter CpG island $[25,26]$. In this study, we determined the methylation profiles of as many as thirty four genes in a cohort consisting of 53 astrocytoma patients and established the concordant methylation behavior of up to three targets. Our observations should provide new insights into the DNA methylation epigenetic defects in human astrocytoma.

\section{Methods}

All the experiments were performed according to protocols described previously [18]. The primer pairs for the methylation specific PCR were either adopted (APC, BRCA1, CDH1, DAPK1, hMLH1, p14 ARF, p15 INK4b, RASSF1A, RB1 and $V H L$ ) or designed according to the same principle with assistance of the software packages for the CpG islands identification http://www.uscnor ris.com/cpgislands and the primer design http://microgen.ouhsc.edu/cgi-bin/primer3 www.cgi [Additional file $1]$.

\section{Tissue samples}

\section{Tissue samples and DNA preparation}

With the informed consent of all patients and approval of the ethics committee, the tumor samples were collected from astrocytoma patients $(n=53)$ during operation at the Tiantan Neurosurgical Hospital in Beijing. The pathological classification of tumor tissues was carried out and the stage of each astrocytoma patients was determined according to the WHO classification [1]. No significant geographic impart was observed as patients came from different places in China and went to Beijing for treatment. In addition, the compatible tissues (normal tissues distant from the lesions) were surgically obtained from three non-astrocytoma patients [gangliocytoma (21 years old, male), angiocavernoma (49 years old, male) and meningioma (54 years old, female)] as the normal controls, which have been subjected to the proper pathological evaluation.

Total genomic DNA was extracted from frozen tissue specimens (50 - $100 \mathrm{mg}$ ) according to a standard protocol with some modifications $[18,27]$. Frozen pulverized powders of the specimens were re-suspended with $2 \mathrm{ml}$ lysis buffer: $50 \mathrm{mM}$ Tris- $\mathrm{HCl}$ pH 8.0, $50 \mathrm{mM}$ EDTA, 1\% SDS, $10 \mathrm{mM} \mathrm{NaCl}$ plus $100 \mu \mathrm{g} / \mathrm{ml}$ boiling-treated RNase A (Sigma). Following one hour of incubation at $37^{\circ} \mathrm{C}$, Proteinase K (Roche, USA) was added to the cellular lysates for a final concentration of $100 \mu \mathrm{g} / \mathrm{ml}$ and the digestion was carried out at $55^{\circ} \mathrm{C}$ for 2 hours. Organic extractions with a half volume of Phenol/Chloroform/Isoamyl alcohol (1:1:0.04) were repeatedly carried out until no visible interphase remained after centrifugation. DNA was precipitated from the aqueous phase in the presence of $0.3 \mathrm{M}$ $\mathrm{NaOAc}$ pH 7.0 and two and a half volumes of ethanol and followed by one 70\% ethanol-washing and dissolved at $65^{\circ} \mathrm{C}$ for 30 minutes with $0.2-0.4 \mathrm{ml}$ TE $(10 \mathrm{mM}$ Tris$\mathrm{HCl} \mathrm{pH} 7.4$ and $1 \mathrm{mM}$ EDTA)and stored at $4^{\circ} \mathrm{C}$ till use. The DNA concentrations were calculated according to the $\mathrm{OD}_{260 \mathrm{~nm}}$ readings.

Bisulphate treatment of DNA and Methylation specific PCR (MSP) The methylation status of the promoter CpG islands of thirty four genes in all DNA samples was analyzed by MSP on the sodium-bisulfite converted DNA [18]. In detail, 10 $\mu \mathrm{g}$ DNA in $50 \mu \mathrm{l}$ TE was incubated with $5.5 \mu \mathrm{l}$ of $3 \mathrm{M}$ $\mathrm{NaOH}$ at $37^{\circ} \mathrm{C}$ for 10 minutes, followed by a 16 hour treatment at $50^{\circ} \mathrm{C}$ after adding $30 \mu$ of freshly prepared $10 \mathrm{mM}$ hydroquinone and $520 \mu \mathrm{l}$ of freshly prepared 3.6 $\mathrm{M}$ sodium-bisulfite at $\mathrm{pH}$ 5.0. The DNA was desalted using a home-made dialysis system with $1 \%$ agarose (detailed protocol will be provided upon request). The DNA in the desalted sample (approximately $100 \mu \mathrm{l}$ in volume) was denatured at $37^{\circ} \mathrm{C}$ for 15 minutes with $5.5 \mu \mathrm{l}$ of $3 \mathrm{M} \mathrm{NaOH}$ followed by ethanol precipitation with $33 \mu \mathrm{l} 8$ $\mathrm{M} \mathrm{NH}_{4} \mathrm{OAC}$ and $300 \mu \mathrm{l}$ ethanol. After washing with $70 \%$ 
ethanol, the gently dried DNA pellet was dissolved with $30 \mu \mathrm{l} \mathrm{TE}$ at $65^{\circ} \mathrm{C}$ for $10 \mathrm{~min}$. The DNA sample was finally stored at $-20^{\circ} \mathrm{C}$ until further use. PCR reaction was carried out in a volume of $15 \mu \mathrm{l}$ with $50 \mathrm{ng}$ or less template DNA with FastStart Taq polymerase (Roche, Germany) as follows. After an initial heat denaturing step 4 minutes treatment at $94^{\circ} \mathrm{C}, 30$ cycles of $92^{\circ} \mathrm{C}$ for $15 \mathrm{sec}$, varying temperatures with primer pairs (Additional file 1) for 15 sec and $72^{\circ} \mathrm{C}$ for $20 \mathrm{sec}$, was carried out. The PCR products were separated by $1.2 \%$ ethidium bromide containing agarose gel electrophoresis with $1 \times \mathrm{TAE}$ and visualized under UV illumination. To verify the PCR results, representative bands from each target were gelpurified and cloned into T-vector (Promega, USA) followed by automatic DNA sequencing provided by BuoCai (Shanghai, China). Only verified results are presented in this report.

To optimize the MSP procedure, the M. Sss I treated DNA was used as the methylated control template. In detail, the DNA from a normal liver tissue of the healthy liver donor $[18,24]$ was batch cleaved with EcoR I, followed by M. Sss I treatment according to the manufacture's instruction (New England Biol., Boston, USA) for over night. The purified DNA was bisulphate treated as usual and subjected to MSP with the primer pairs for each of thirty three genes (except for the MAGEA1 gene), and only the verified targets were included for the study of the astrocytoma tissues.

\section{Statistical analysis}

The methylation data were dichotomized as 1 for the coexistence of the methylated and unmethylated alleles, 2 for methylated allele only and 0 for the unmethylated for both alleles to facilitate statistical analysis using contingency tables. The methylation profiles of each individual gene (in percentage) classified by the genders and grading of the patients were presented both in table and in plot.
The statistic analyses for the association between the methylation profile of the gene and each of the clinicalpathological parameters were carried out with the statistics package http://www.R-project.org/, where both Pearsong's Chi-square test with Upton's adjustment and Fisher exact test http://www.R-project.org/ were used to examine the tissue samples with the low expected values. The relative frequency with a 95\% confidence interval $(\mathrm{P}<0.05)$ for a binomial distribution was calculated for the whole as well as each subtype of astrocytoma patients.

The concordant methylation behavior of the genes was established by comparing frequency of co-occurrence of 2 to 3 target subsets with a mathematic method, namely Discovery of Association Rules [28], which is frequently utilized for association analysis.

\section{Demethylation of U25 I cells with 5-Aza-2'-deoxycytidine}

U251 cells (an established glioma cell line) were cultured in DEME plus $10 \%$ new born calf serum at $37^{\circ} \mathrm{C}$ in a $5 \%$ $\mathrm{CO}_{2}$ atmosphere. When cell culture reached $50 \%$ confluence, they were treated with 5-Aza-2'-deoxycytidine (Sigma A3656) at the final concentration 10 and $20 \mathrm{nM}$, respectively for 3 days. The primer pairs for the RT-PCR (Table 1) was either adopted from published papers or designed with an assistance of the software http://microgen.ouhsc.edu/cgi-bin/primer3 www.cgi. The total RNA was extracted with Trizol solution according to manufacturer's instruction (Invitrogen, USA), and cDNA was obtained using the Supertranscript plus reverse transcriptase with the oligo-dT as primers. PCR with single pair of the target primers run for 15 cycles, followed by another 15 cycle PCR reactions in the presence of the betaactin primers (Table 1) (the parameter of each cycle is $94^{\circ} \mathrm{C} 20^{\prime \prime}, 60^{\circ} \mathrm{C}$ for $20^{\prime \prime}$ and $72^{\circ} \mathrm{C}$ for $30^{\prime \prime}$ ). The resulted PCR products were visualized under UV illumination after an electrophoretic separation on a $1.2 \%$ agarose. The methylation status of the target was analyzed by MSP.

Table I: The primers for RT-PCR analysis

\begin{tabular}{|c|c|c|c|}
\hline Primer Name & sequence & PCR Product Length (bp) & Accession Number \\
\hline beta-actin L & AAGTACTCCGTGTGGATCGG & 616 & NM_00II0I \\
\hline beta-actin $\mathrm{R}$ & TCAAGTTGGGGGACAAAAAG & & \\
\hline $\mathrm{cdh} / 3 \mathrm{f}$ & GCTGGACTGGATGTTGGATT & 246 & NM_00I 257 \\
\hline $\operatorname{cdh} \mid 3 t$ & TTGAGGGTTGGTGTGGATTT & & \\
\hline magea Irf & ACCTGACCCAGGCTCTGT & 401 & NM_004988 \\
\hline magealrt & CTCACTGGGTTGCCTCTG & & \\
\hline mgmtrf & AAACGCACCACACTGGAC & 404 & NM_0024I2 \\
\hline imgmtrt & AGGATGGGGACAGGATTG & & \\
\hline p73f & AGATGAGCAGCAGCCACAG & 218 & NM_005427 \\
\hline p73t & GTACTGCTCGGGGATCTTCA & & \\
\hline rassflarf & GTCTGCCTGGACTGTTGC & 401 & NM_007I82 \\
\hline rassflart & AGCAGGGCCTCAATGACT & & \\
\hline
\end{tabular}


Table 2: The clinical and pathological profiles of the patients

\begin{tabular}{|c|c|c|c|c|}
\hline & & & Astrocytoma & Non astrocytoma \\
\hline \multicolumn{5}{|l|}{ Gender } \\
\hline & female & & 27 & 1 \\
\hline & male & & 26 & 2 \\
\hline \multicolumn{5}{|l|}{ Age, $y$} \\
\hline & $<40$ & & 27 & 1 \\
\hline & $40-60$ & & 23 & 2 \\
\hline & $>60$ & & 3 & 0 \\
\hline \multirow[t]{2}{*}{ Grade } & \multicolumn{2}{|c|}{ Age } & & \\
\hline & Mean & Range & & \\
\hline I & 39.1 & 10 to 62 & 14 & \\
\hline ॥ & 33.1 & 4 to 50 & 15 & \\
\hline III & 40.4 & I to 72 & 12 & \\
\hline \multirow[t]{3}{*}{ IV } & 44.6 & 22 to 66 & 12 & \\
\hline & Recurrent & & 4 & \\
\hline & Primary & & 8 & \\
\hline
\end{tabular}

\section{Results and discussion Clinical-pathological classification}

To establish the methylation profile of thirty four genes during the process of astrocytoma development, we recruited 53 astrocytoma patients (27 female and 26 male; 49 primary and 4 recurrent) for this study. 14 cases were pathologically classified at the Grade I pilocytic astrocytoma (10-62 years old, mean: 39.1; 9 female, 5 male), 15 cases at the Grade II diffuse astrocytoma (4-50 years old, mean: $33.1 ; 10$ female, 5 male), 12 cases at the Grade III anaplastic astrocytoma (1-72 years old; mean: $40.4 ; 4$ female, 8 male), and 12 cases (including 4 recurrent cases) at the Grade IV glioblastoma (22-66 years old, mean: 44.6; SD = 22-66, 4 female, 8 male) (Table 2). The normal brain tissues distant from the lesions were also obtained from three non-astrocytoma patients who underwent brain surgery as normal controls in this study.

\section{Aberrant Methylation profiling in astrocytoma}

The technical considerations

The methylation-specific PCR (MSP) is widely used for methylation profiling of the genes in human cancers for both its easiness and sensitivity. However, the necessary steps have to be taken to eliminate both false positive and negative results. Comparing the MSP-data with the nonPCR data by Southern analysis of the methylation sensitive restriction enzyme is a valuable choice, as our previous work where the hypomethylated status of both $p 14^{A R F}$ and $p 15^{I N K 4 b}$ genes shown by MSP was confirmed by Southern analysis [18]. Alternatively, the PCR reaction with the in vitro methylated genomic DNA (by M. Sss I) as template would be an ideal positive control for the absence of methylated targets in tumor tissue samples. By taking extra caution, we carried out MSP of all the targets with the M. Sss I treated normal liver DNA as positive con- trol templates, except for the MAGEA1 gene was unmethylated in the normal liver tissue. While only the PCR reaction designated to the unmethylated template gave rise to the detectable bands with the parental DNA, the PCR bands were evident in both reactions with the M. Sss I treated DNA (Additional File 2). Therefore, failure to detect the methylated alleles with the tissue samples should genuinely reflect the lack of methylated targets. To control the false positive with either pair of primers, the representative PCR products, were T-cloned and sequenced. Only the positive PCR results with the expected sequence profiles were scored and analyzed further.

The methylation profiling of thirty four targets in astrocytoma Eleven of the thirty four target genes were previously studied either in astrocytoma or other types of tumors. The published PCR conditions for these genes: APC, BRCA1, CDH1， DAPK1, hMLH1, p14 ARF, p15 INK4b, p16 INK4a RASSF1A, RB1 and VHL (Additional file 1) were adopted to enable the relevant inter-study comparisons if necessary. The remaining twenty three targets were selected from a list of genes http://www.missouri.edu/ hypermet/ list_of_promoters.htm displaying the altered pattern of the promoter CpG island in various biological settings including cancers. Their $\mathrm{CpG}$ islands were identified via bioinformatical tools http://www.uscnorris.com/cpgis lands and the primer pairs were designed accordingly http://micro-gen.ouhsc.edu/cgi-bin/ primer3 www.cgi[ 18,24$]$. Some of these thirty four genes have been shown to play a role in carcinogenesis, whereas the others have no obvious association with human carcinogenesis. Since it is still disputed whether DNA methylation mediated the gene silencing is causative in the malignant transformation of cell, we specifically selected 
both sets of genes in this study. The "cancer unrelated" genes selected encode erythropoiesis (EPO) [29], a ubiquitously expressed transcription factor (OCT6) [30], and the myogenesis lineage-specific transcription factor (MYOD1) [31]. The majority of the cancer associated genes examined were tumor suppressor genes including genes operating in the $R B 1 / p 16^{I N K 4 a}$ pathway ( $p 14^{A R F}$, $p 15^{I N K 4 b}, p 16^{I N K 4 a}$, and RB1) [32], and two cyclin-dependent kinase inhibitors ( $p 27^{K I P 1}\left[33\right.$ ] and $\left.p 57^{K I P 2}\right)$ [34]. Other genes in this subset were a $p 53$ analogue:(p73) [33,35], two alternative forms of a tumor suppressors in the Ras mediated signal transduction pathway (RASSF1A, and RASSF1C [36]), VHL [37], APC [38], PTEN [6], the deleted in bladder cancer chromosome region candidate 1 (DBCCR1) [39], and the Wilms tumor 1 gene(WT1) [40]. We included the genes encoding the cell membrane proteins or nuclear receptors which act actively in the intercellular interactions: melanoma specific antigen A1 (MAGEA1) [41], caveolin 1 (CAV) [42], chondroitin sulfate proteoglycan 2 (CSPG2) [43], androgen receptor (AR) [44], and cadherins (CDH1 [45] and CDH13) [46]. Three genes implicated in signal transduction were also selected: cyclin a1 [47], the interferon regulatory factor 7 (IRF7), and a serine/threonine kinase 1 (Peutz-Jeghers syndrome) gene (LKB1) [14]. There were the genes encoding the O-6methylguanine-DNA methyltransferase (MGMT) [14]and metallothionein 1 A gene $(M T 1 A)$ [48] which play a key role in the cellular response to alkalyting agents and heavy metal stress. The genes acting in DNA repair process were hMLH1 [49], and BRCA1 [50], while four genes are involved in apoptosis (APAF1 [51], DAPK1 [15], and SURVIVIN [23]). Finally, the proto-oncogenes in this group were represented by v-abl homologue $1(A B L)$ [52] (Additional files 3,4,5,6,7,8,9).

\section{The genes displayed the uniformly unmethylated profiles in astrocytoma}

Of the unmethylated genes in all samples tested, EPO was a cancer unrelated gene, while "cancer associated" genes included $A B L(1), A P A F 1(2), A P C(3), B R C A 1(5), C A V(6)$, CDH13(8), DAPK1(11), hMLH1(14), LKB1(16), p14 ${ }^{A R F}(22), p 15^{I N K 4 b}(23), p 27^{K I P 1}(25), p 57^{K I P 2}(26), P T E N$ (28), RASSF1C(30), RB1(31), SURVIVIN(32), and VHL(33) genes (Additional files 3,4,5,6,7,8,9).

Lack of hypermethylation of the RB1 gene in our observation was inconsistent with a recent report that the hypermethylated RB1 gene was detected in $19 \%$ of astrocytoma patients (26/136 cases analyzed) [53]. Since the same region was looked at in this work, the discrepancy noticed may simply reflect the inherent difference in the patient cohorts between our work and the published [53].

The genetic defects affecting the PTEN gene contributed to the pathogenesis of astrocytoma [54]. Lack of the hyper- methylation of its promoter CpG island in both normal and astrocytoma tissues indicates that the DNA hypermethylation mediated silencing mechanism unlikely plays a significant role in the PTEN inactivation that occurs frequently in astrocytoma. This explanation might also be applicable to the no change type of methylation behavior for both the tumor associated genes $(A B L(1)$, APAF1(2), APC(3), BRCA1(5), CAV(6), CDH13 (8), DAPK1(11), hMLH1(14), LKB1(16), p14 ARF(22), p15 INK4b (23), p27KIP1 (25), p57KIP2(26), PTEN (28), RASSF1C(30), RB1(31), SURVIVIN(32), and VHL(33) genes) and the "cancer unrelated" genes (EPO (14)) (Additional files 3,4,5,6,7,8,9).

The genes with the astrocytoma specific alteration in methylation As shown in Additional files 3,4,5,6,7,8,9, thirteen genes (CDH1 (7), CSPG2(9), cyclin a1(10), DBCCR1(12), IRF7(15), MGMT(18), MT1A(19), MYOD1(20), OCT6(21), p16 INK4a (24), p73(27), RASSF1A (39) and WT1(34)) were unmethylated in all three normal controls. In contrast, these genes were hypermethylated to various extents in the astrocytoma samples. The following six genes were marginally hypermethylated: $p 1 \sigma^{I N K 4 a}$, EPO, DBCCR1 and MYOD1 genes were hypermethylated in $1.9 \%(1 / 53)$ of astrocytoma tissues, while both $\mathrm{CDH} 13$ and cyclin a1 genes were hypermethylated in 5.7\% (3/53) of astrocytoma cases. No significant changes of these six genes shown in here acted against the notion that DNA methylation related mechanisms underline potential inactivation of this set of genes in the pathogenesis of astrocytoma. The infrequent hypermethylation of the $p 16^{I N K 4 a}$ gene in astrocytoma was a total surprise, as it was frequently reported hypermethylated in various human tumors tested, including in HCC where we have previously found that the p16INK4a, MYOD1, CDH13 and cyclin a1 genes were frequently methylated $[18,24]$. To further verify this unexpected observation, we repeated the MSP analysis on five astrocytoma samples (shown unmethylated) along with one HCC sample (previously shown heterozygously methylated). As shown in panel 1, Fig. 1, MSP patterns of the astrocytoma as well as HCC tissues remained the same. The identities of which were also confirmed by sequencing (panel 2, Fig. 1), showing that while the MSP products with the primers specific to the methylated targets in the HCC sample (Z92K) contained CpGs, the unmethylated targets in all the five astrocytoma tissues $(21,22,26$, A11 and B6) contained TpGs. Therefore, lack of hypermethylation of the $p 16^{I N K 4 a}$ gene in astrocytoma was unlikely incorrect, which is consistent with a recent report that inactivation of the p16 INK4a gene in $48 \%$ of astrocytoma cases was genetic [55].

The remaining 7 targets were hypermethylated more frequently, occurring in $26.4 \%$ to $69.8 \%$ (14 to $37 / 53$ ) of astrocytoma cases. The OCT6 gene was hypermethylated 


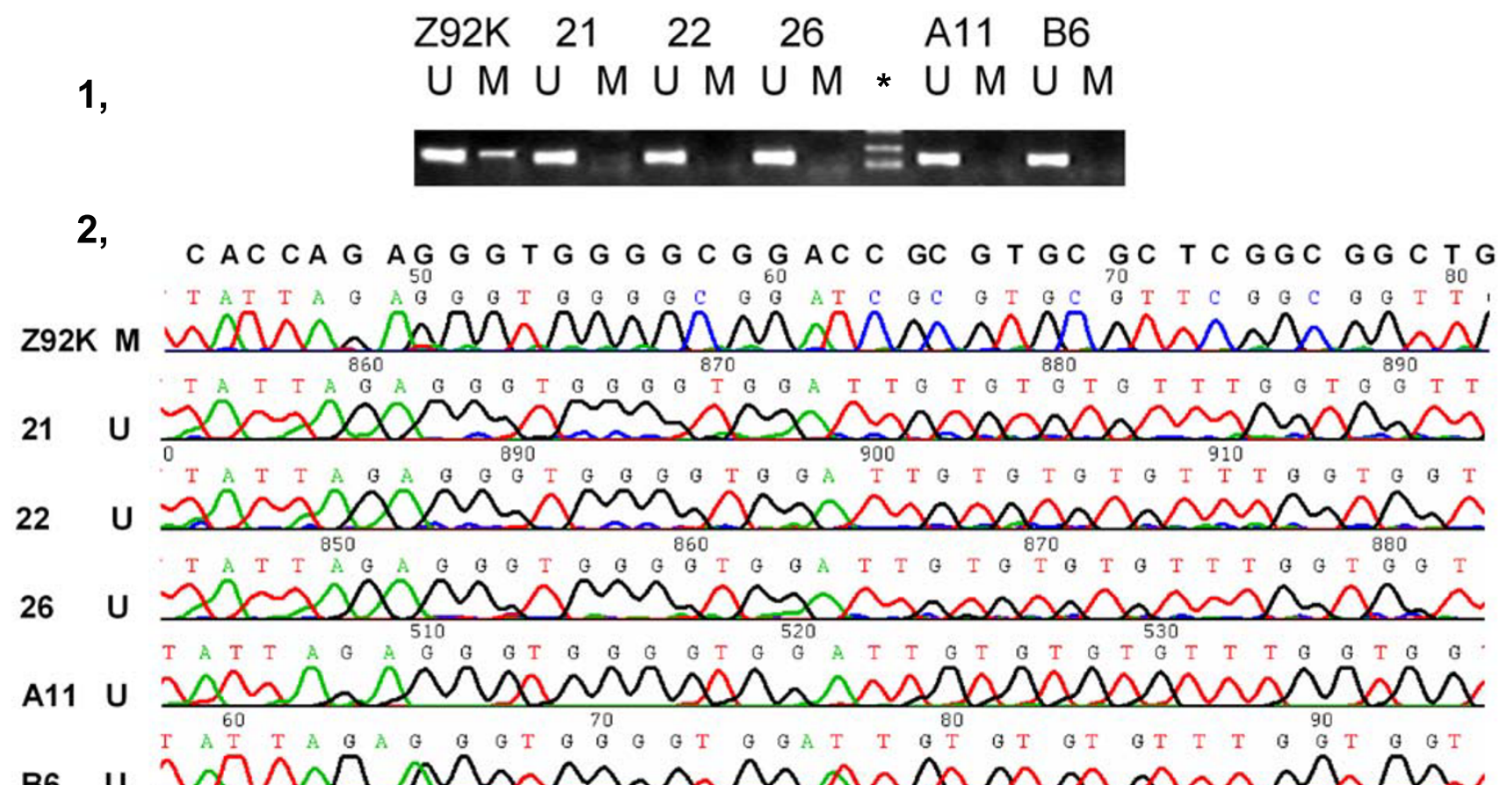

Figure I

$\mathrm{MSP} /$ sequencing analyses of the pI6INK4a gene in astrocytoma and hepatocellular carcinoma Both electrophoretic patterns of the PCR products of the pI $6^{1 N K 4 a}$ in each of five astrocytoma cases (2I, 22, 26, AII and B6) and one HCC case (Z92K) (indicated respectively, at the top of figures) were presented. To indicate the methylation status, the sequenced data are aligned with the wild-type sequence.

in $30.2 \%$ of the astrocytoma cases (16/53). Despite of the association of the OCT6 methylation with the aging process reported previously, we found no significant correlation/association of the OCT6 methylation to any clinicalpathological features, including age, gender and clinical grading of the patients. The significance of such a prevalent occurrence of the hypermethylated OCT6 gene remains to be determined. The RASSF1A (hypermethylated in $37 / 53$ cases, $69.8 \%$ ) is a variant of the recently identified tumor suppressor, the RASSF1 gene that acts at downstream of the Ras mediated apoptotic pathway and is capable of binding to Ras in a GTP dependent manner [36]. The RASSF1A gene has a more extended 5' part and its promoter $\mathrm{CpG}$ island displays a tumor specific hypermethylated profile in a variety of tumors, HCC in particular. Furthermore, lack of the RASSF1A expression in nineteen established tumor cell lines correlates with the hypermethylated state of its promoter CpG island [36]. The RASSF1C gene has its own promoter CpG island, but is not methylated in any tumors. The methylation behavior of these two genes was very similar to our previous observation in hepatocellular carcinoma, where 22/29 cases $(79 \%)$ had the fully methylated $1 \mathrm{~A}$ along with the unmethylated $1 \mathrm{C}$ variants [18]. As shown in Additional file $4,5,6,7,8,9$, the RASSF1A promoter-CpG island was methylated in $69.8 \%$ (37/53) of astrocytoma tissues, while the $\mathrm{C}$ variant was not methylated in any astrocytoma tissues. The hypermethylated state of the RASSF1A promoter $\mathrm{CpG}$ island was not correlated with gender, age and clinical grading. Consistent with the hypermethylated status of the RASSF1A gene in U251 cells, no expression at the mRNA level was detected. Partial demethylation of its promoter by the treatment with 5-Aza-2'-deoxycytidine indeed resulted in its transcription (Fig. 2). 


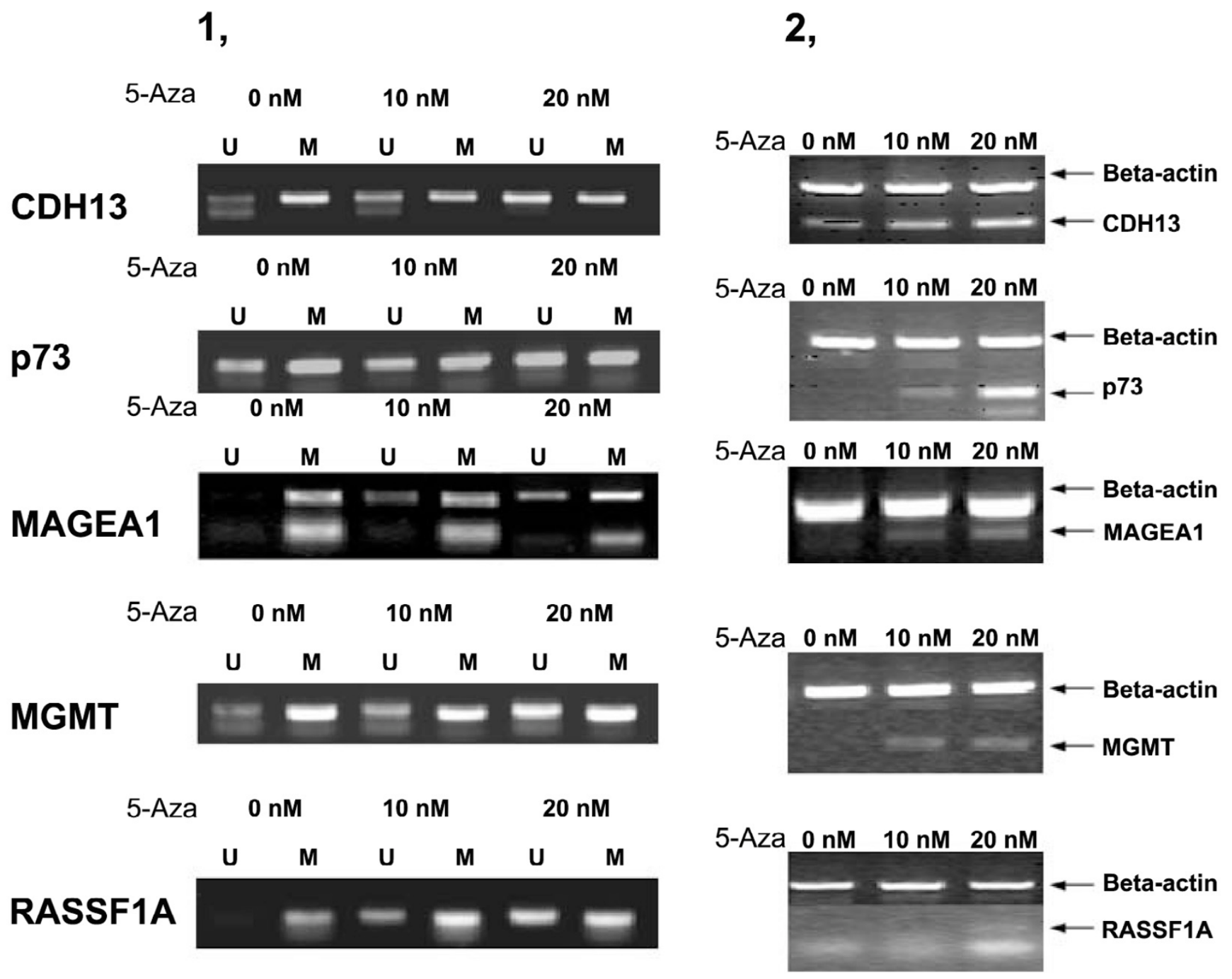

Figure 2

The methylation state and expression profiles of the CDHI3, p73, MAGEAI, MGMT and RASSFIA genes in U25I astrocytoma cells before and after the demethylation treatment with 5-Aza-2'-deoxycytidine U25I cells were subjected to the 10 and 20 nM 5-Aza-2'-deoxycytidine (5-Aza) treatment for 3 days before both DNA and RNA were prepared for either MSP analyses or RT-PCR assessments. Panels; A, the methylation status of the CDHI3, p73, MAGEAI, MGMT and RASSFIA genes and B, the expression profiles of each of these five genes, respectively in U25I cells.

The p73 gene encodes a homologue to TP53, and loss of its heterozygosity has been observed in up to $90 \%$ of oligodendrogliomas and in $10-25 \%$ of diffuse astrocytoma $[56,57]$. In this study, we found that the $p 73$ gene was prevalently methylated $(25 / 53,47.2 \%)$ with no significant association with any clinical-pathological parameters, such as gender and the WHO grading. The occurrence of the hypermethylated $p 73$ gene was more prevalent in our results than a recent report which detected the hypermethylated $p 73$ gene in $18 \%(5 / 28)$ of the WHO grade IV but not in grade III astrocytoma [35]. Again, even the partially elevated demethylated status of its promoter CpG island in U251 cells resulted in reactivation of $p 73$ transcription (Fig. 2).

Both genetic defects and epigenetic abnormalities of the WT1 gene have been etiologically implicated in the formation of the Wilm's tumor [58]. In this study, we also found that the WT1 gene was hypermethylated in $30 \%$ (16/53) of cases, implying its possible involvement in the formation of astrocytoma.

Tumor resistance to the cytotoxic chemotherapies may result from the disrupted apoptosis programs and remains 
a major obstacle in cancer treatment. In this study, the interferon regulatory factor 7 (IRF7) gene was analyzed. The analogue (IRF1) of IRF7 has been implicated in the IFN gamma mediated apoptosis with a profound effect on the chemo-sensitivity of tumor cells $[59,60]$. In consistence with the recent report that the IRF7 expression was negatively regulated by the promoter methylation [61], we found that the IRF7 gene was hypermethylated in astrocytoma (14/53, 26.5\%) (Additional file 4,5,6,7,8,9), with a strong male inclination $(11 / 26,42.3 \%$ verse the female group: $\left.3 / 27,11 \%, \chi^{2}=6.632, P=0.014\right)$. Although the gender difference remains to be understood, such a strong male association with IRF7 hypermethylation may have prognostic value.

$\mathrm{O}$ (6)-methylguanine-DNA methyltransferase (MGMT), a DNA repair enzyme, removes alkylating adducts from the $\mathrm{O}(6)$ position of guanine and protects cells from cytotoxic and mutagenic stress. Silencing of the MGMT gene has been suggested to predispose the neoplastic clones to acquisition of the guanine to adenine point mutations in K-ras and p53 [62] and is associated with low-levels of micro-satellite instability in colorectal cancer [63]. We found that the MGMT gene was prevalently hypermethylated in astrocytoma $(35 \%, 19 / 53)$, and its transcription could be reactivated by demethylation with 5-Aza-2'deoxycytidine in U251 cells (Fig. 2). Hence, the MGMT hypermethylation in astrocytoma may indeed have the pathological significance. In this connection, a recent report suggested that the astrocytoma sensitivity to the alkylating type of chemotherapeutics might be contributed by the hypermethylated MGMT gene [64]. Expression of the metallothionein I A (MT1A) is inducible by a number of adversary agents such as heavy metals and oxidative stress. Both basal and inducible expression of this gene has been impaired in various tumor cell lines and attributed to the hypermethylated state of this gene [48]. In this study, we found that the MT1A gene was hypermethylated in $30 \%(16 / 53)$ of cases, with no significant gender and grading difference. The functional and pathological implications of the MT1A hypermethylation in astrocytoma remain to be established.

Cadherins, the calcium-dependent proteins, contribute to various biological processes such as differentiation, migration and extra-cellular signal transduction of cell. Loss of expression of both E-cadherin (CDH1) and H-cadherin $(C D H 13)$ has been found in parallel with the hypermethylated promoter CpG islands in various cancers $[65,66]$. In this study, we found that the $\mathrm{CDH} 1$ gene was hypermethylated in $32.8 \%(17 / 53)$ of astrocytoma tissues, while the CDH13 gene was not methylated in all the astrocytoma tissues examined (Additional files $4,5,6,7,8,9)$. In contrast, in human hepatocellular carcinoma [18], the $C D H 1$ gene was unmethylated, while the
CDH13 gene was frequently hypermethylated. Obviously, the molecular basis for tumor type specific methylation patterns of these two genes remains to be determined.

Although the hypermethylation mediated gene silencing of the tumor suppressor genes is at the focal point of the epigenetic studies, demethylated status of the promoter CpG islands has been linked to the tumor associated activation of the normally silenced genes [19-23]. Therefore, we also studied both MAGEA1 and SURVIVIN genes. The promoter $\mathrm{CpG}$ islands were hypermethylated in normal tissues (for MAGEA1 in HCC [18] and for SURVIVIN in ovarian cancer [23]) and demethylated in parallel with the transcriptional activation in tumor cells. The unmethylated status of the SURVIVIN gene in astrocytoma is consistent with the over-expression of this gene (unpublished observations). However, its unmethylated status in all the non-astrocytoma tissues acts odd with the notion that its demethylation is associated with pathogenesis in human ovarian cancer reported previously [23].

Our previous studies indicated that demethylation of the promoter CpG island was correlated well with the overexpression profile of the MAGEA1 gene $[18,21]$ in HCC. The MAGEA1 gene was fully hypermethylated in all four cases of the normal liver tissues but significantly demethylated in HCC tissues $(21 / 28,75 \%)$. It was found fully hypermethylated in all the three control tissues and in $74.5 \%(40 / 53)$ of the astrocytoma tissues and partially hypermethylated $(13 / 53,25.5 \%)$ in the other astrocytoma tissues. The occurrence of the MAGEA1 demethylation in HCC differed significantly from astrocytoma $(75 \%$ verse $25.5 \%, \mathrm{P}<0.001)$. As it was fully methylated in the normal tissue, the partial hypermethylation (both hypermethylated and demethylated alleles existed) would imply that the event resulting in the loss of the hypermethylation state of the MAGEA1 gene indeed occurred in astrocytoma and should be scored positive for the changes in the methylation pattern in this study. The same principle has been applied for the opposite changes from the unmethylated pattern in the normal control to the partial or full hypermethylated status of all the other genes in astrocytoma tissues. It was also found that the partial demethylated status of the MAGEA1 gene in U251 cells induced by 5-Aza-2'-deoxycytidine occurred co-currently with activation of its transcription (Fig. 2).

The gender association of the methylation profiles of the AR and IRF7 gene in astrocytoma

By statistic analysis with both Pearson Chi-Square and Fisher's Exact tests, associations of the DNA methylation profiles of the targets displaying no less than 24.5\% changes (the RASSF1A, p73, MGMT, CDH1, OCT6, WT1 as well as MAGEA1 genes) with the clinical pathological parameters (age, grading and gender) were assessed. The 
methylation profiles of the $A R$ and IRF7 genes were found gender-oriented.

The AR gene encodes the androgen receptor that plays a key role in the signal transduction pathways in response to the male steroid hormone, androgen and has been reported to be inactivated via the epigenetic mechanism in prostate cancers [67]. Physiologically, the AR gene should express exclusively in the somatic cells in males, while lacking of its expression in females is likely mediated by DNA methylation based mechanisms. Indeed, the hypermethylated along with the unmethylated AR genes were only found in the normal female brain tissue, but not from two male non-astrocytoma samples. The hypermethylation of the AR gene occurred frequently in the female group $(81.5 \%, 22 / 27)$ but not in any males $(0 \%$, $0 / 26, \chi^{2}=36.22, P=0.000$ ). It may simply be gender associated and do not have any significant relevance to carcinogenesis of astrocytoma. It was also noticed that hypermethylation of the IRF7 gene displayed an opposite gender inclination, detected in $11 \%$ of the female patients (3/27), and $42 \%$ of male patients $\left(11 / 26, \chi^{2}=? 6.632, \mathrm{P}=\right.$ $0.014)$. Despite of the difficulty to offer a mechanistic interpretation, the potential prognostic value of such a gender-associated phenomenon might be worthwhile exploring in future.

Demethylation by 5-Aza-2'-deoxycytidine treatment of the astrocytoma cells in culture resulted in partial demethylation and reactivated expression of the genes

The hypermethylated status of the promoter CpG island has been linked to gene transcription silencing in a number of biological settings. The effect of the astrocytoma associated changes in the methylated state of the promoter $\mathrm{CpG}$ islands detected in this study on gene expression was assessed in U251 astrocytoma cells treated with the a demethylating agent, 5-Aza-2'-deoxycytidine. We used MSP to establish the methylation status of the promoter $\mathrm{CpG}$ island of all the genes with the astrocytoma associated methylation changes (Additional files $3,4,5,6,7,8,9)$ in U251 astrocytoma cells, and analyzed the ability of 5-Aza-2'-deoxycytidine to demethylate five genes, as measured by MSP, and reactivate their expression, as detected by RT-PCR.

As shown in panel 1 of Fig. 2, while the CDH13, MAGEA1 and $p 73$ genes were heterozygously methylated, both MGMT and RASSF1A genes were fully hypermethylated in U251 cells. The CDH13 gene was found expressed, while the rest transcriptionally inert as measured by the RT-PCR. Although both methylated and unmethylated alleles for p73 and MGMT genes were evident in U251 cells, no expression was detected, indicating that the unmethylated allele may remain silent by the other mechanisms, including the genetic defects at critical control region. By the 5-
Aza-2'-deoxycytidine treatment, both demethylation of the promoter CpG island and activation of transcription of these five genes were achieved (Fig. 2). Despite of the fact that demethylation of the promoter $\mathrm{CpG}$ islands was incomplete in samples treated with $20 \mathrm{nM} 5$-Aza-2'-deoxycytidine (Fig. 2), the expression of this five genes was either induced (the MAGEA1, MGMT, p73 and RASSF1A genes) or elevated (the CDH13 gene).

\section{The concordant methylation behavior of the promoter $\mathrm{Cp} G$ islands of the genes in Astrocytoma}

The DNA methylation mediated epigenetic changes also display the tumor type specific patterns, which seem to reflect the differentiation and maturation histories of the cell lineages as well as the aging process during which both global hypo- and local hyper-methylation occur. Hypermethylation of the promoter CpG islands in accord with the transcriptional silencing of the tumor suppressor genes, such as the p $16^{\text {INK4a }}$, and RASSF1A genes, has been well established in human tumors $[16,68]$. However, it remains unclear whether there is a common mechanism for the concurrent methylation changes of multiple tumor suppressor genes in tumors. To address this matter, it is necessary to examine a large number of genes for frequent changes in methylation in any type of human tumors. The concordant methylation behavior of multiple genes was firstly detected in colon cancer [69], based upon a comprehensive methylation profiling of over thirty genes. In this study, we have profiled the methylation status of thirty four genes in a cohort of 53 astrocytoma and 3 nonastrocytoma patients. Twenty three of these genes had not been studied previously in astrocytoma. As far as the number of the genes is concerned, this study is the most extensive in the astrocytoma field to our knowledge. Among thirty four genes, sixteen genes exhibited the astrocytoma associated changes in methylation profiles of the promoter $\mathrm{CpG}$ islands and nine genes displayed rather frequent changes (the occurrence $\geq 13 / 53$, frequency $\geq$ 24.5\%) (Additional file 8).

Four of 53 cases $(7.5 \%)$ maintained the same methylation profile as the normal control. The rest 49 cases (92.5\%) suffered from the methylation changes as much as no less than one target, an occurrence was significantly lower than in HCC, where all the cases displayed methylation changes affecting no less than three targets in the studies involved with twenty or twenty four targets $[18,24]$, indicating that alterations in DNA methylation loccur more frequently in HCC than in astrocytoma. This may be contributed by the apparent anatomic inaccessibility of the brain to environmental adverse factors in comparison to the liver. The size of the subsets containing various number of the target affected (from one to nine) ranged from 1 to 11 cases, and peaked with 10 cases at three and 11 cases at five target subsets (Additional file 9). To iden- 
tify the most frequent changes of the target sets (one to three), a mathematic method called "the Discovery of Association Rules" [28] was used. The co-occurrence (case number/the total) and frequency (\% of the total) of any subset of the targets that changed in methylation together in astrocytoma were counted and compared. In the entire cohort of patients in this study, the most altered target was the RASSF1A gene, $69.8 \%(37 / 53)$. The two genes that most altered together were the RASSF $1 A$ and $p 73$ genes, hypermethylation of which was found in 20 (37.7\%). Three genes that changed together were the former two plus $C D H 1$ or OCT6, hypermethylation of which occurred in $20.8 \%$ cases $(11 / 53)$ (Column 2, a, Additional file 10). Furthermore, the occurrence in methylation change in any target in the two gene subsets was $79.3 \%$ (42/530 and in three gene subsets was $81.1-83 \%$ (43-44/53) (Column 3, a, Additional file 10).

Since the hypermethylated $A R$ is associated closely with the female gender of the astrocytoma patients and devoid of any association with the formation of astrocytoma, it was taken out from this analysis. Hypermethylation of the RASSF1A gene occurred in 21 female cases $(77.8 \%, 21 /$ 27). Both RASSF1A and WT1 were hypermethylated in 13 $(13 / 27,48.1 \%)$; and the former two plus the hypermethylated $p 73$ or $C D H 1$ or OCT 6 were found in 9 female cases $(9 / 27,33.3 \%)$, respectively (Column 2, b, Additional file $10)$. The subsets in the male patient group showed very different patterns. The single to three target subsets were the RASSF1A (16/26, 61.5\%); the RASSF1A and IRF7 (10/ $26,38.5 \%)$; and the former two plus the $p 73$ or MGMT or MT1A (5/26, 19.2\%), respectively (c, Additional file 10). In Grade I astrocytoma, the subsets for one, two and three targets were RASSF1A (10/14, 71.4\%), RASSF1A plus p73 $(6 / 14,42.9 \%)$, and the former two plus either WT1 or IRF7 or MAGEA1 as well as RASSF1A plus CDH1 and WT1 $(3 / 14,21.4 \%)$. For Grade II astrocytoma, the corresponding sets consisted of the RASSF1A $(12 / 15,80 \%)$, the RASSF1A and MGMT or IRF7 $(5 / 15,33.3 \%)$, and the RASSF1A and MGMT plus $p 73$ or OCT6, or MT1A, or WT1 as well as the RASSF1A and IRF7 and MT1A (3/15, 20\%), respectively. For Grading III astrocytoma, those subsets were composed of the RASSF1A $(8 / 12,66.7 \%)$, the RASSF1A and CDH1 $(5 / 12,41.7 \%)$, and the formal two plus MGMT (4/12, 33.3\%), respectively. For Grading IV astrocytoma, the comparative subsets contained the RASSF1A or $p 73(7 / 12,58.3 \%)$, the RASSF1A and $p 73$ (6/ $12,50 \%)$, and the former two plus MGMT or OCT6 $(4 / 12$, $33.3 \%$ ), respectively. (d-g, Additional file 10).

Our methylation profiling efforts described in this report provided the following informative targets: the RASSF1A, p73, WT1, MGMT, CDH1, OCT6, and IRF7 genes. The established concordant methylation profiles of these eight genes (Additional file 10) may provide useful clues for the epigenetic biomarker selection to for the novel diagnostic and prognostic assays of astrocytoma. The hypermethylated status of this lest of genes in the serum, and biopsies of the suspected astrocytoma patients may serve as good diagnostic indicators, if they can be reliably detected. With the death/survival profiles of this cohort of astrocytoma patients available in the future, the methylation profile established in this study may have certain prognostic value.

\section{Abbreviations}

HCC: Hepatocellular carcinoma; PCR: polymerase chain reaction; MSP: methylation specific PCR; $A B L$ : v-abl Abelson murine leukemia viral oncogene homolog 1; APAF1: apoptotic protease activating factor; $A P C$ : adenomatosis polyposis coli; $A R$ : androgen receptor; $B R C A 1$ : breast cancer 1; CAV: caveolin 1, caveolae protein; $C D H 1$ : cadherin type 1, E-cadherin; CDH13: cadherin 13, H-cadherin; CSPG2: chondroitin sulfate proteoglycan 2 (versican); cyclin a1: cyclin A1; DAPK1: death-associated protein kinase 1; DBCCR1: deleted in bladder cancer chromosome region candidate 1; EPO: erythropoietin; $h M L H 1$ : mutL homolog 1, colon cancer, nonpolyposis type 2; IRF7: interferon regulatory factor 7 ; LKB1: serine/threonine kinase 11 (Peutz-Jeghers syndrome); MAGEA1: melanoma antigen, family A, 1 (directs expression of antigen MZ2-E); MGMT: O-6-methylguanine-DNA methyltransferase; MT1A: metallothionein 1A (functional); MYOD1: myogenic factor 3; OCT6: POU domain, class 3 , transcription factor $1 ;$ p $14^{A R F}$ : the alternative reading frame of the cyclin-dependent kinase inhibitor 4a; p15INK4b: cyclin-dependent kinase inhibitor $4 \mathrm{~b}$; $p 16^{I N K 4 a}$ : cyclin-dependent kinase inhibitor $4 \mathrm{a}$; $27^{\mathrm{KIP} 1}$ : cyclindependent kinase inhibitor 1B (p27, KIP1); p57 KIP2: cyclin-dependent kinase inhibitor 1C (p57, KIP2); p73: tumor protein p73; PTEN: phosphatase and tensin homolog; RASSF1A: ras association (RalGDS/AF-6) domain family 1 protein isoform 1a; RASSF1C: ras association (RalGDS/AF-6) domain family 1 protein isoform $1 \mathrm{c}$; RB1: retinoblastoma 1; VHL: von Hippel-Lindau syndrome; WT1: Wilms tumor 1.

\section{Competing interests}

None declared.

\section{Authors' contributions}

JY, HYZ, JG, executing the experiments;

SL and JHL, providing the patient samples;

WL and YFW, carrying out the mathematic analyses of the data

JDZ: designing and organizing experiments as well as completing manuscript. 


\section{Additional material}

\section{Additional File 1}

The target promoter $C p G$ islands and the primer pairs for methylation specific PCR. This file contains his study.

Click here for file

[http://www.biomedcentral.com/content/supplementary/14712407-4-65-S1.pdf]

\section{Additional File 2}

Methylation profiles of thirty three genes on the in vitro methylated genomic DNA by M. Sss I methyl transferase. The Eco RI restricted genomic DNA from the liver tissue of a healthy donor was in vitro methylated overnight with $M$. Sss I methyl transferase and subjected to the MSP analysis, followed by electrophoresis in a 1.3\% agarose gel. *, the DNA size markers, NL, the untreated sample, $U$ and $M, M S P$ with the pair of primers specific to the unmethylated and methylated targets, respectively. Panels: $1, A B L ; 2, A P A F 1 ; 3, A P C ; 4, A R ; 5, B R C A 1 ; 6$, CAV; 7, CDH1; 8, CDH13; 9, CSPG2; 10, cyclin a1; 11, DAPK1; 12, DBCCR1; 13, EPO; 14, hMLH1; 15, IRF7; 16, LKB1; 17, MGMT; 18, MT1A; 19, MYOD1; 20, OCT6; 21, p14 ARF; 22, p15 INK4b; 23, p16INK4a; 24, p27 KIP1; 25, p57KIP2; 26, p73; 27, PTEN; 28, RASSF1A; 29, RASSF1C; 30, RB1; 31, SURVIVIN; 32, VHL and 33, WT1. Click here for file

[http://www.biomedcentral.com/content/supplementary/14712407-4-65-S2.pdf]

\section{Additional File 3}

Methylation profiles of thirty four genes in astrocytoma (part I). Both electrophoretic patterns of the representative PCR products of each of thirty four targets (indicated respectively, at the top of figures) and the sequencing verification of the one representative PCR product were presented. To indicate the methylation status, the sequenced data are aligned with the wild-type sequence. ${ }^{*}$, size markers, the bands of $250 \mathrm{bp}$ and $100 \mathrm{bp}$ were shown. $U$, the unmethylated; $M$, the hypermethylated. Panels: $1, A B L ; 2$, APAF1; 3, APC; 4, AR; 5, BRCA1; 6, CAV; 7, CDH1; 8, CDH13; 9, CSPG2; 10, cyclin a1; 11, DAPK1 and 12, DBCCR1.

Click here for file

[http://www.biomedcentral.com/content/supplementary/14712407-4-65-S3.pdf]

\section{Additional File 4}

Methylation profiles of the promoter $C p G$ islands of thirty four genes in astrocytoma (part II). Both electrophoretic patterns of the representative PCR products of each of thirty four targets (indicated respectively, at the top of figures) and the sequencing verification of the one representative PCR product were presented. To indicate the methylation status, the sequenced data are aligned with the wild-type sequence. ${ }^{*}$, size markers, the bands of $250 \mathrm{bp}$ and $100 \mathrm{bp}$ were shown. $U$, the unmethylated; $M$, the hypermethylated. Panels: 13, EPO; 14, hMLH1; 15, IRF7; 16, LKB1; 17, MAGEA1; 18, MGMT; 19, MT1A; 20, MYOD1; 21, OCT6 and 22, p14 $4^{A R F>}$.

Click here for file

[http://www.biomedcentral.com/content/supplementary/14712407-4-65-S4.pdf]

\section{Additional File 5}

Methylation profiles of the promoter $C p G$ islands of thirty four genes in astrocytoma (part III). Both electrophoretic patterns of the representative PCR products of each of thirty four targets (indicated respectively, at the top of figures) and the sequencing verification of the one representative PCR product were presented. To indicate the methylation status, the sequenced data are aligned with the wild-type sequence. ${ }^{*}$, size markers, the bands of $250 \mathrm{bp}$ and $100 \mathrm{bp}$ were shown. $U$, the unmethylated; $M$,

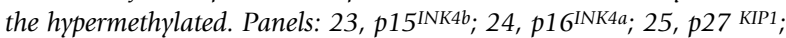
26, p57KIP2; 27, p73; 28, PTEN; 29, RASSF1A; 30, RASSF1C; 31, RB1; 32, SURVIVIN; 33, VHL and 34, WT1.

Click here for file

[http://www.biomedcentral.com/content/supplementary/14712407-4-65-S5.pdf]

\section{Additional File 6}

The summary of the astrocytoma cases displaying no or changes in the methylation profiles (part I). The frequency (\%) of the astrocytoma displaying no or the changes in the methylation profile of each target from the normal control were counted and presented in table as well as plotted in the figure below. The filled, shading and empty boxes indicate the cases where only hypermethylated allele, both hypermethylated and unmethylated alleles and only unmethylated alleles were detected, respectively. The frequency (\%) of the hypermethylated targets (except for the MAGEA1 gene) among the total cases was scored for positive changes in astrocytoma. The MAGEA1 was fully methylated $(3 / 3,100 \%)$ in the control, and become partially demethylated in some astrocytoma, therefore, demethylation of the MAGEA1 in astrocytoma was scored as positive changes. Sub-tables: $a$, the female patient group, $b$, the male patient group, and $c$, the control.

Click here for file

[http://www.biomedcentral.com/content/supplementary/14712407-4-65-S6.pdf]

\section{Additional File 7}

The summary of the astrocytoma cases displaying no or changes in the methylation profiles (part II). The frequency (\%) of the astrocytoma displaying no or the changes in the methylation profile of each target from the normal control were counted and presented in table as well as plotted in the figure below. Sub-tables $d$-h, the WHO grading I to IV, respectively; The filled, shading and empty boxes indicate the cases where only hypermethylated allele, both hypermethylated and unmethylated alleles and only unmethylated alleles were detected, respectively. The frequency (\%) of the hypermethylated targets (except for the MAGEA1, where the heterozygously hypermethylated) among the total cases was presented in the plot.

Click here for file

[http://www.biomedcentral.com/content/supplementary/14712407-4-65-S7.pdf]

\section{Additional File 8}

The occurrences and frequency of changes in methylation. ${ }^{*}$, One of three cases was methylated; **, The MAGEA1 gene was fully methylated in the normal tissues and partially demethylated in astrocytoma patients as indicated in the relevant cells. Therefore, the astrocytoma associated changes in methylation of this gene is opposite to the rest, i.e., demethylation rather than hypermethylation. Figure is each cells are the frequency in $\%$ and occurrence (case number).

Click here for file

[http://www.biomedcentral.com/content/supplementary/14712407-4-65-S8.pdf] 


\begin{abstract}
Additional File 9
The summary of changes in the methylation pattern in subsets. Both occurrence (case number) and frequency (\%) for the subsets having no change in methylation and changes in one to nine genes are presented in $\%$ and (case number) in the top half of table, which was also plotted. Both occurrence (case number) and frequency (\%) for the subsets having no change in methylation and changes in, at least, one to nine genes are presented in $\%$ and (case number) in the bottom half of table.

Click here for file

[http://www.biomedcentral.com/content/supplementary/14712407-4-65-S9.pdf]

\section{Additional File 10}

The summary of the concordant methylation behavior of the hypermethylated targets in astrocytoma. The co-occurrence (/total case) and frequency (\%) of a panel subsets consisting of one to three targets were treated with method "Discovery Association Rules" and presented. Sub-tables: $a$, the total, $b$, the female, $c$, the male, and $d-g$, the grade I to IV, respectively. Column 1 is the number of target in each subset. Column 2 is the cooccurrence (case number/total) (frequency in \%). Column 3 is the occurrence of any single target in each subsets, presented in case number (frequency \%). The column 4 is the gene(s) in subset. N.B., In view of the strong female inclination of the AR methylation and lacking of any association with astrocytoma, $A R$ has been taken off from this analyses. Click here for file

[http://www.biomedcentral.com/content/supplementary/14712407-4-65-S10.pdf]
\end{abstract}

\section{Acknowledgements}

This work was supported by the National High Technology Research and Development Program of China (863 Program) (200IAA2 I70II, 2002AA2Z3352), the Major State Basic Research Development Program of China (973 Program) (G I99805 I004), and the Science Foundation of Shanghai Municipal Government (02DJI4056) to Jingde Zhu. Thanks are due to J. Xin for his assistance in the statistical analysis of the data and D. Niu, J. Li, P. Wang, and C. Jiang for the comments on this manuscript.

\section{References}

I. Kleihues P, Cavenee W: Astrocytic tumours. In: Pathology \& Genetics Tumours of the Nervous System Edited by: Kleihues P, Cavenee W. Lyon: IARC Press; 2000:9-54.

2. Cancer Incidence and Mortality in China, 1993-1997 (Selected Cities and Counties). Ist edition. Beijing: China Publishing House of Medical Sciences and Technologies; 1998.

3. Libermann TA, Nusbaum HR, Razon N, Kris R, Lax I, Soreq H, Whittle N, Waterfield MD, Ullrich A, Schlessinger J: Amplification, enhanced expression and possible rearrangement of EGF receptor gene in primary human brain tumours of glial origin. Nature 1985, 3 I 3(5998): | 44-I47.

4. Hegi ME, zur Hausen A, Ruedi D, Malin G, Kleihues P: Hemizygous or homozygous deletion of the chromosomal region containing the p I6INK4a gene is associated with amplification of the EGF receptor gene in glioblastomas. Int J Cancer 1997, 73(1):57-63.

5. Ichimura K, Bolin MB, Goike HM, Schmidt EE, Moshref A, Collins VP: Deregulation of the $\mathrm{p} I 4 A R F / M D M 2 / p 53$ pathway is a prerequisite for human astrocytic gliomas with G I-S transition control gene abnormalities. Cancer Res 2000, 60(2):417-424.

6. Ichimura K, Schmidt EE, Goike HM, Collins VP: Human glioblastomas with no alterations of the CDKN2A (pI6INK4A, MTSI) and CDK4 genes have frequent mutations of the retinoblastoma gene. Oncogene 1996, 13(5): 1065-1072.

7. Mashiyama S, Murakami Y, Yoshimoto T, Sekiya T, Hayashi K: Detection of $\mathrm{p} 53$ gene mutations in human brain tumors by single- strand conformation polymorphism analysis of polymerase chain reaction products. Oncogene $1991,6(8):|3| 3-13 \mid 8$.

8. Li J, Yen C, Liaw D, Podsypanina K, Bose S, Wang SI, Puc J, Miliaresis C, Rodgers L, McCombie R, Bigner SH, Giovanella BC, Ittmann M, Tycko B, Hibshoosh H, Wigler MH, Parsons R: PTEN, a putative protein tyrosine phosphatase gene mutated in human brain, breast, and prostate cancer. Science 1997 , 275(5308): 1943-1947.

9. Jones PA: Epigenetics in carcinogenesis and cancer prevention. Ann N Y Acad Sci 2003, 983:213-219.

10. Feninberg A: Cancer epigenetics takes center stage. Proc Natl Acad Sci U SA 200I, 98(2):392-394.

II. Eden A, Gaudet F, Waghmare A, Jaenisch R: Chromosomal instability and tumors promoted by DNA hypomethylation. Science 2003, 300(56 I8):455.

12. Gaudet F, Hodgson JG, Eden A, Jackson-Grusby L, Dausman J, Gray $\mathrm{JW}$, Leonhardt $\mathrm{H}$, Jaenisch R: Induction of tumors in mice by genomic hypomethylation. Science 2003, 300(56 I8):489-492.

13. Chen RZ, Pettersson U, Beard C, Jackson-Grusby L, Jaenisch R: DNA hypomethylation leads to elevated mutation rates. Nature 1998, 395(6697):89-93.

14. Esteller M, Fraga MF, Guo M, Garcia-Foncillas J, Hedenfalk I, Godwin AK, Trojan J, Vaurs-Barriere C, Bignon YJ, Ramus S, Benitez J, Caldes T, Akiyama Y, Yuasa Y, Launonen V, Canal MJ, Rodriguez R, Capella G, Peinado MA, Borg A, Aaltonen LA, Ponder BA, Baylin SB, Herman JG: DNA methylation patterns in hereditary human cancers mimic sporadic tumorigenesis. Hum Mol Genet 200I, I0(26):300I-3007.

15. Zochbauer-Muller S, Fong KM, Virmani AK, Geradts J, Gazdar AF, Minna JD: Aberrant promoter methylation of multiple genes in non-small cell lung cancers. Cancer Res 200I, 6I (I):249-255.

16. Rosas SL, Koch W, da Costa Carvalho MG, Wu L, Califano J, Westra W, Jen J, Sidransky D: Promoter hypermethylation patterns of p 16, O6-methylguanine-DNA-methyltransferase, and deathassociated protein kinase in tumors and saliva of head and neck cancer patients. Cancer Res 200I, 6 I (3):939-942.

17. Foster SA, Wong DJ, Barrett MT, Galloway DA: Inactivation of p I6 in human mammary epithelial cells by $\mathrm{CpG}$ island methylation. Mol Cell Biol I998, I 8(4): I793-I80I.

18. Yu J, Ni M, Xu J, Zhang H, Gao B, Gu J, Chen J, Zhang L, Wu M, Zhen $\mathrm{S}$ : Methylation profiling of twenty promoter-CpG islands of genes which may contribute to hepatocellular carcinogenesis. BMC Cancer 2002, 2(I):29.

19. Cui H, Onyango P, Brandenburg S, Wu Y, Hsieh CL, Feinberg AP: Loss of imprinting in colorectal cancer linked to hypomethylation of HI 9 and IGF2. Cancer Res 2002, 62(22):6442-6446.

20. Cho B, Lee H, Jeong S, Bang YJ, Lee HJ, Hwang KS, Kim HY, Lee YS, Kang GH, Jeoung DI: Promoter hypomethylation of a novel cancer/testis antigen gene CAGE is correlated with its aberrant expression and is seen in premalignant stage of gastric carcinoma. Biochem Biophys Res Commun 2003, 307(I):52-63.

21. Mou DC, Cai SL, Peng JR, Wang Y, Chen HS, Pang XW, Leng XS, Chen WF: Evaluation of MAGE-I and MAGE-3 as tumour-specific markers to detect blood dissemination of hepatocellular carcinoma cells. Br J Cancer 2002, 86(I): $110-116$.

22. Suyama $T$, Ohashi $H$, Nagai $H$, Hatano $S$, Asano $H$, Murate $T$, Saito $H$ Kinoshita T: The MAGE-Al gene expression is not determined solely by methylation status of the promoter region in hematological malignancies. Leuk Res 2002, 26(I2): III3-III8.

23. Hattori M, Sakamoto H, Satoh K, Yamamoto T: DNA demethylase is expressed in ovarian cancers and the expression correlates with demethylation of $\mathrm{CPG}$ sites in the promoter region of c-erbB-2 and survivin genes. Cancer Lett 200I, I69(2):155-164.

24. Yu J, Zhang HY, Ma ZZ, Lu W, Wang YF, Zhu JD: Methylation profiling of twenty four genes and the concordant methylation behaviours of nineteen genes that may contribute to hepatocellular carcinogenesis. Cell Res 2003, I3(5):319-333.

25. Alonso ME, Bello MJ, Gonzalez-Gomez P, Arjona D, Lomas J, de Campos JM, Isla A, Sarasa JL, Rey JA: Aberrant promoter methylation of multiple genes in oligodendrogliomas and ependymomas. Cancer Genet Cytogenet 2003, I 44(2): I 34- I 42.

26. Gonzalez-Gomez P, Bello MJ, Arjona D, Lomas J, Alonso ME, De Campos JM, Vaquero J, Isla A, Gutierrez M, Rey JA: Promoter hypermethylation of multiple genes in astrocytic gliomas. Int J Oncol 2003, 22(3):60I-608. 
27. Clark SJ, Harrison J, Paul CL, Frommer M: High sensitivity mapping of methylated cytosines. Nucleic Acids Res 1994, 22(I 5):2990-2997.

28. Agrawal $R$, Imielinski $T$, Swami $A$ : Mining association rules between sets of items in large databases. ACM SIGMOD Conference 1993:207-216.

29. Yin $\mathrm{H}$, Blanchard $\mathrm{KL}$ : DNA methylation represses the expression of the human erythropoietin gene by two different mechanisms. Blood 2000, 95(I): III-II9.

30. Sauter $P$, Matthias P: Coactivator OBF-I makes selective contacts with both the POU-specific domain and the POU homeodomain and acts as a molecular clamp on DNA. Mol Cell Biol 1998, I 8( I 2):7397-7409.

31. Chen B, Dias P, Jenkins JJ 3rd, Savell VH, Parham DM: Methylation alterations of the MyoD I upstream region are predictive of subclassification of human rhabdomyosarcomas. Am J Pathol 1998, I52(4): 107|-1079.

32. Sherr CJ, McCormick F: The RB and p53 pathways in cancer. Cancer Cell 2002, 2(2): 103-II2.

33. Kibel AS, Christopher M, Faith DA, Bova GS, Goodfellow PJ, Isaacs WB: Methylation and mutational analysis of p27(kipl) in prostate carcinoma. Prostate 200I, 48(4):248-253.

34. Li Y, Nagai H, Ohno T, Yuge M, Hatano S, Ito E, Mori N, Saito $H$, Kinoshita T: Aberrant DNA methylation of p57(KIP2) gene in the promoter region in lymphoid malignancies of $B$-cell phenotype. Blood 2002, I00(7):2572-2577.

35. Watanabe T, Huang H, Nakamura M, Wischhusen J, Weller M, Kleihues $\mathrm{P}$, Ohgaki $\mathrm{H}$ : Methylation of the p73 gene in gliomas. Acto Neuropathol (Berl) 2002, I04(4):357-362.

36. Agathanggelou A, Honorio S, Macartney DP, Martinez A, Dallol A, Rader J, Fullwood P, Chauhan A, Walker R, Shaw JA, Hosoe S, Lerman MI, Minna JD, Maher ER, Latif F: Methylation associated inactivation of RASSFIA from region $3 \mathrm{p} 21.3$ in lung, breast and ovarian tumours. Oncogene 200|, 20(12):|509-|5|8.

37. Linehan WM, Lerman MI, Zbar B: Identification of the von Hippel-Lindau (VHL) gene. Its role in renal cancer. Jama 1995 273(7):564-570.

38. Neibergs HL, Hein DW, Spratt JS: Genetic profiling of colon cancer. J Surg Oncol 2002, 80(4):204-2I3.

39. Habuchi T, Luscombe M, Elder PA, Knowles MA: Structure and methylation-based silencing of a gene (DBCCRI) within a candidate bladder cancer tumor suppressor region at 9q32q33. Genomics 1998, 48(3):277-288.

40. Laux DE, Curran EM, Welshons WV, Lubahn DB, Huang TH: Hypermethylation of the Wilms' tumor suppressor gene CpG island in human breast carcinomas. Breast Cancer Res Treat 1999, 56(I):35-43

4I. De Smet C, De Backer O, Faraoni I, Lurquin C, Brasseur F, Boon T: The activation of human gene MAGE-I in tumor cells is correlated with genome-wide demethylation. Proc Natl Acad Sci U S A 1996, 93( I 4):7|49-7|53.

42. Cui J, Rohr LR, Swanson G, Speights VO, Maxwell T, Brothman AR: Hypermethylation of the caveolin-I gene promoter in prostate cancer. Prostate 200I, 46(3):249-256

43. Toyota M, Ho C, Ahuja N, Jair KW, Li Q, Ohe-Toyota M, Baylin SB, Issa JP: Identification of differentially methylated sequences in colorectal cancer by methylated CpG island amplification. Cancer Res 1999, 59(1 0):2307-2312.

44. Sasaki M, Tanaka Y, Perinchery G, Dharia A, Kotcherguina I, Fujimoto $S$, Dahiya R: Methylation and inactivation of estrogen, progesterone, and androgen receptors in prostate cancer. J Natl Cancer Inst 2002, 94(5):384-390.

45. Grady WM, Willis J, Guilford PJ, Dunbier AK, Toro TT, Lynch H, Wiesner G, Ferguson K, Eng C, Park JG, Kim SJ, Markowitz S: Methylation of the CDHI promoter as the second genetic hit in hereditary diffuse gastric cancer. Nat Genet 2000, 26(I): I6-I7.

46. Toyooka S, Toyooka KO, Harada K, Miyajima K, Makarla P, Sathyanarayana UG, Yin J, Sato F, Shivapurkar N, Meltzer SJ, Gazdar AF: Aberrant methylation of the CDHI3 (H-cadherin) promoter region in colorectal cancers and adenomas. Cancer Res 2002 62(1 2):3382-3386.

47. Muller C, Readhead C, Diederichs S, Idos G, Yang R, Tidow N, Serve $\mathrm{H}$, Berdel WE, Koeffler HP: Methylation of the cyclin AI promoter correlates with gene silencing in somatic cell lines, while tissue-specific expression of cyclin AI is methylation independent. Mol Cell Biol 2000, 20(9):3316-3329.
48. Ghoshal K, Majumder S, Li Z, Dong X, Jacob ST: Suppression of metallothionein gene expression in a rat hepatoma because of promoter-specific DNA methylation. J Biol Chem 2000 , 275(I):539-547.

49. Viswanathan M, Tsuchida N, Shanmugam G: Promoter hypermethylation profile of tumor-associated genes pl6, pI5, hMLHI, MGMT and E-cadherin in oral squamous cell carcinoma. Int J Cancer 2003, I 05(I):4 I-46.

50. Fearon ER: BRCAI and E-cadherin promoter hypermethylation and gene inactivation in cancer-association or mechanism? J Natl Cancer Inst 2000, 92(7):5I5-5I7.

51. Soengas MS, Capodieci P, Polsky D, Mora J, Esteller M, Opitz-Araya X, McCombie R, Herman JG, Gerald WL, Lazebnik YA, CordonCardo C, Lowe SW: Inactivation of the apoptosis effector Apaf-I in malignant melanoma. Nature 200I, 409(68 I 7):207-2II

52. Rachmilewitz EA: The role of methylation in CML. Przegl Lek 2000, 57(Suppl I):25-26.

53. Gonzalez-Gomez P, Bello MJ, Alonso ME, Arjona D, Lomas J, de Campos JM, Isla A, Rey JA: CpG island methylation status and mutation analysis of the RB I gene essential promoter region and protein-binding pocket domain in nervous system tumours. $\mathrm{Br}$ / Cancer 2003, 88( I): |09-I |4.

54. Fan X, Munoz J, Sanko SG, Castresana JS: PTEN, DMBTI, and pl 6 alterations in diffusely infiltrating astrocytomas. Int J Oncol 2002, 2 I (3):667-674.

55. Ghimenti C, Fiano V, Chiado-Piat L, Chio A, Cavalla P, Schiffer D: Deregulation of the $\mathrm{pI} 4 \mathrm{ARF} / \mathrm{Mdm} 2 / \mathrm{p} 53$ pathway and $\mathrm{GI} / \mathrm{S}$ transition in two glioblastoma sets. I Neurooncol 2003, 6 I (2): $95-102$

56. Dong S, Pang JC, Hu J, Zhou LF, Ng HK: Transcriptional inactivation of TP73 expression in oligodendroglial tumors. Int J Cancer 2002, 98(3):370-375

57. Loiseau $\mathrm{H}$, Arsaut J, Demotes-Mainard J: p73 gene transcripts in human brain tumors: overexpression and altered splicing in ependymomas. Neurosci Lett 1999, 263(2-3): I73-176.

58. Satoh Y, Nakagawachi $T$, Nakadate $H$, Kaneko $Y$, Masaki Z, Mukai T, Soejima H: Significant Reduction of WTI Gene Expression, Possibly Due to Epigenetic Alteration in Wilms' Tumor. J Biochem (Tokyo) 2003, I 33(3):303-308.

59. Tomita Y, Bilim V, Hara N, Kasahara T, Takahashi K: Role of IRF-I and caspase-7 in IFN-gamma enhancement of Fas-mediated apoptosis in ACHN renal cell carcinoma cells. Int J Cancer 2003. I 04(4):400-408.

60. Detjen KM, Murphy D, Welzel M, Farwig K, Wiedenmann B, Rosewicz S: Downregulation of p2 I (waf/cip-I) mediates apoptosis of human hepatocellular carcinoma cells in response to interferon-gamma. Exp Cell Res 2003, 282(2):78-89.

61. Lu R, Au WC, Yeow WS, Hageman N, Pitha PM: Regulation of the promoter activity of interferon regulatory factor-7 gene. Activation by interferon and silencing by hypermethylation. J Biol Chem 2000, 275(4I):3 I805-31812.

62. Esteller M, Risques RA, Toyota M, Capella G, Moreno V, Peinado MA Baylin SB, Herman JG: Promoter hypermethylation of the DNA repair gene $O(6)$-methylguanine-DNA methyltransferase is associated with the presence of $G: C$ to $A: T$ transition mutations in p53 in human colorectal tumorigenesis. Cancer Res 200I, 6 I (I 2):4689-4692

63. Whitehall VL, Walsh MD, Young J, Leggett BA, Jass JR: Methylation of 0-6-methylguanine DNA methyltransferase characterizes a subset of colorectal cancer with low-level DNA microsatellite instability. Cancer Res 200 I, 6 I (3):827-830.

64. Esteller M, Garcia-Foncillas J, Andion E, Goodman SN, Hidalgo OF, Vanaclocha V, Baylin SB, Herman JG: Inactivation of the DNArepair gene MGMT and the clinical response of gliomas to alkylating agents. N Engl J Med 2000, 343( I 9): | 350- | 354.

65. Toyooka KO TS, Virmani AK, Sathyanarayana UG, Euhus DM, Gilcrease M, Minna JD, Gazdar AF: Loss of expression and aberrant methylation of the CDHI3 (H-cadherin) gene in breast and lung carcinomas. Cancer Res 200 I, 6 I ( I I ):4556-4560.

66. Azarschab P, Stembalska A, Loncar MB, Pfister M, Sasiadek MM, Blin $\mathrm{N}$ : Epigenetic control of E-cadherin (CDHI) by CpG methylation in metastasising laryngeal cancer. Oncol Rep 2003, I 0(2):501-503

67. Yamanaka M, Watanabe M, Yamada Y, Takagi A, Murata T, Takahashi $H$, Suzuki $H$, Ito $H$, Tsukino $H$, Katoh $T$, Sugimura $Y$, Shiraishi $T$ : 
Altered methylation of multiple genes in carcinogenesis of the prostate. Int J Cancer 2003, 106(3):382-387.

68. Pfeifer GP, Yoon JH, Liu L, Tommasi S, Wilczynski SP, Dammann R: Methylation of the RASSFIA gene in human cancers. Biol Chem 2002, 383(6):907-914.

69. Toyota M, Ohe-Toyota M, Ahuja N, Issa JP: Distinct genetic profiles in colorectal tumors with or without the CpG island methylator phenotype. Proc Natl Acad Sci U S A 2000, 97(2):710-715.

\section{Pre-publication history}

The pre-publication history for this paper can be accessed here:

http://www.biomedcentral.com/1471-2407/4/65/prepub

Publish with Bio Med Central and every scientist can read your work free of charge

"BioMed Central will be the most significant development for disseminating the results of biomedical research in our lifetime. " Sir Paul Nurse, Cancer Research UK

Your research papers will be:

- available free of charge to the entire biomedical community

- peer reviewed and published immediately upon acceptance

- cited in PubMed and archived on PubMed Central

- yours - you keep the copyright

Submit your manuscript here:

http://www.biomedcentral.com/info/publishing_adv.asp 